\title{
OBSERVATIONAL STUDY OF EPIDURAL LABOUR ANALGESIA USING BUPIVACAINE AND BUPIVACAINE PLUS TRAMADOL
}

\author{
Neena Gupta1, Sachidanand Guptaㄹ, Apurva Agarwal ${ }^{3}$, Renu Gupta ${ }^{4}$, G. N. Dwivedi ${ }^{5}$, Nishu ${ }^{6}$ \\ 1 Professor, Department of Obstetrics and Gynaecology, GSVM Medical College, Kanpur, Uttar Pradesh. \\ ${ }^{2}$ Associate Professor, Department of Anaesthesiology and Critical Care, Rama Medical College, Kanpur, Uttar Pradesh. \\ ${ }^{3}$ Associate Professor, Department of Anaesthesiology and Critical Care, GSVM Medical College, Kanpur, Uttar Pradesh. \\ ${ }_{4}^{4}$ Associate Professor, Department of Obstetrics and Gynaecology, GSVM Medical College, Kanpur, Uttar Pradesh. \\ ${ }^{5}$ Associate Professor, Department of Paediatrics, GSVM Medical College, Kanpur, Uttar Pradesh. \\ ${ }^{63}$ rd Year Junior Resident, Department of Obstetrics and Gynaecology, GSVM Medical College, Kanpur, Uttar Pradesh.
}

ABSTRACT

\section{BACKGROUND}

The aim of this study is to study the role of epidural for labour analgesia using Bupivacaine and Bupivacaine plus Tramadol.

\section{MATERIALS AND METHODS}

Prospective observational study conducted in Obstetrics Department of GSVM Medical College and other associated hospitals of Kanpur, from 01/01/15 - 31/08/16.

\section{RESULTS}

Epidural analgesia had no adverse effect on duration and outcome of labour as well as neonatal outcome. However, pain relief was significant in epidural analgesia. Further when comparing parturient with Bupivacaine and Bupivacaine plus Tramadol groups, parturient of group Bupivacaine plus Tramadol were found to have earlier onset and longer duration of analgesia and had lesser pain perception as compared to parturient with Bupivacaine only.

\section{CONCLUSION}

Epidural analgesia is an effective method of pain relief. Instead of Bupivacaine alone, Bupivacaine plus Tramadol is more effective for pain relief during labour as an epidural analgesia.

\section{KEYWORDS}

Epidural Analgesia, Bupivacaine, Tramadol.

HOW TO CITE THIS ARTICLE: Gupta N, Gupta S, Agarwal A, et al. Observational study of epidural labour analgesia using bupivacaine and bupivacaine plus tramadol. J. Evolution Med. Dent. Sci. 2016;5(101):7418-7421, DOI: 10.14260/Jemds/2016/1679

\section{BACKGROUND}

Labour pain has been described by the most as the most painful experience a woman can have in her lifetime. If pain is not adequately controlled, it can lead to adverse maternal and foetal outcome and sequel, because of maternal sympathetic activation which in turn predisposes to dysfunctional labour and compromised foetal oxygenation. Continuous research for balanced labour analgesia that provides relief from pain, while preserving motor functions has led to development of ambulatory labour analgesia techniques. Ambulatory epidural analgesia is a popular choice for labour analgesia because ambulation reportedly increases maternal comfort, increases the intensity of uterine contraction, avoids inferior vena cava compression, facilitates foetal head descent and relax the pelvic musculature, all of which can shorten labour. Emphasising the role of epidural analgesia in painless labour

Financial or Other, Competing Interest: None.

Submission 10-11-2016, Peer Review 09-12-2016,

Acceptance 14-12-2016, Published 19-12-2016.

Corresponding Author:

Dr. Nishu,

Room No. 29, Girls P.G. Hostel,

GSVM Medical College,

Swaroop Nagar,

Kanpur-208002,

Uttar Pradesh, India.

E-mail: nishutanwar1988@gmail.com

DOI: $10.14260 /$ jemds/2016/1679 we have studied the ambulatory epidural analgesia using Bupivacaine and Bupivacaine plus Tramadol during labour in terms of onset of analgesia, duration of action and quality of analgesia and its neonatal outcome.

\section{MATERIALS AND METHODS}

Prospective observational study conducted at Department of Obstetrics and Gynaecology, GSVM Medical College and other associated hospitals of Kanpur. Study included healthy parturient with cephalic presentation, 37 - 41 weeks gestation, singleton pregnancy with no associated medical and systemic complications.

Study included 117 parturient, divided into 3 groups.

Group A (39) - who had not been given any analgesia.

Group B (39) - who had been given Bupivacaine $(0.1 \%)$ only.

Group C (39) - who had been given Bupivacaine (0.1\%) plus Tramadol (2 mg/mL).

When cervix will be $3 \mathrm{~cm}$ dilated, epidural analgesia was given using epidural needle. After lumbar injection, analgesia spreads both caudally and to a greater extent cranially with a delay at the L5 and S1 segments due to the large size of these nerve roots.

For effect on CTG parameters, NST was taken 15 minutes before analgesia and every 30 minutes after analgesia. Top up dose was injected through catheter on parturient demand. Following every top up dose, 10-minute monitoring for uterine contractions and effect for adequate analgesia was done. Side effects and complaints noted at 5, 15, 30, 45, 60, 
90, 120, 150 and 180 mins. interval. Time to the first top up dose and additional analgesia required by the mother was recorded. Patient's walking duration was recorded in relation to study time from epidural insertion to delivery time.
Labour was managed and mode of delivery and time of delivery was noted.

\section{RESULTS}

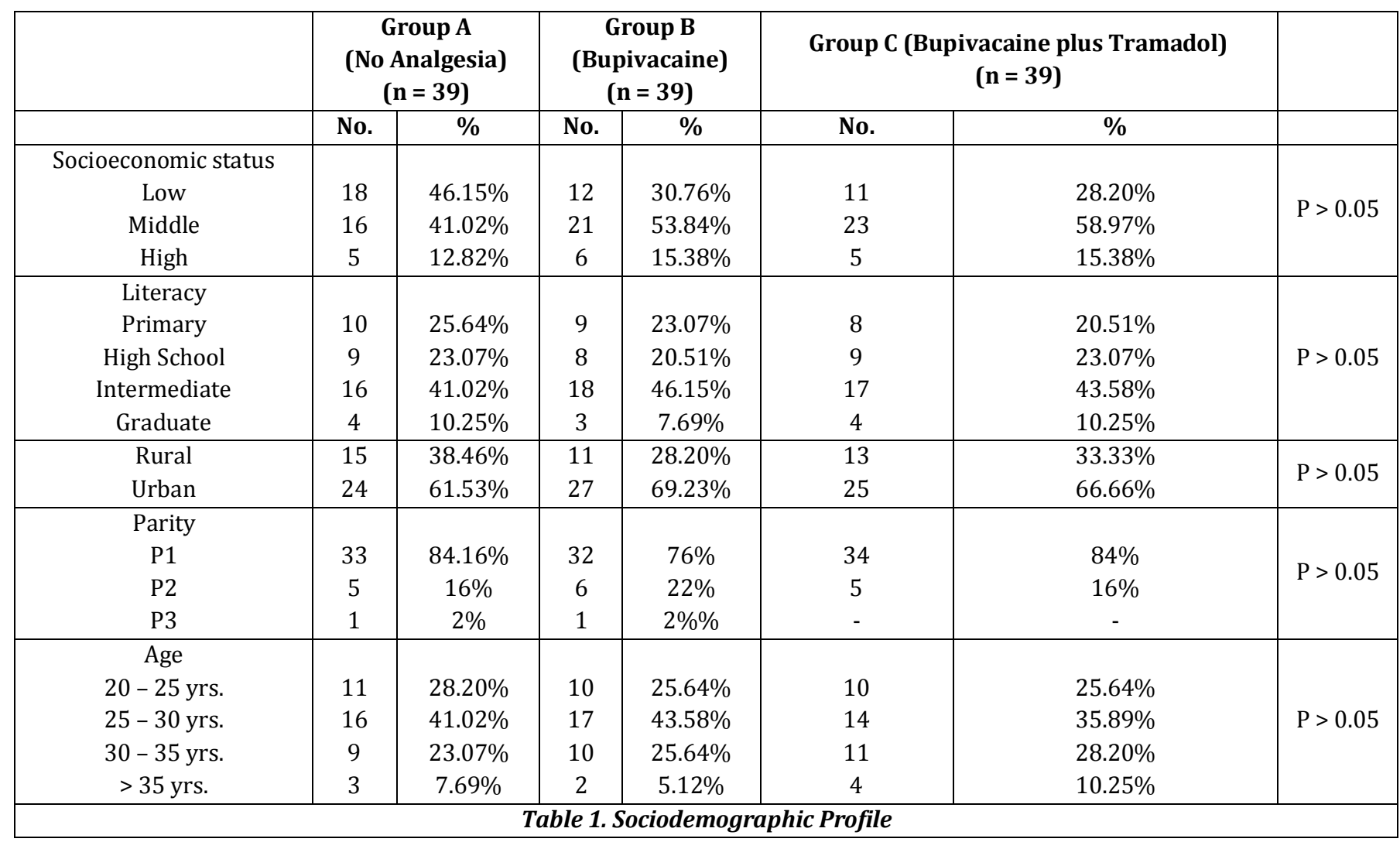

In the study majority of the patients belonged to middle socioeconomic status (52\%), while maximum patients in control group were lying in low socioeconomic status. This was statistically insignificant and also distribution according to educational status educated patients opted for epidural analgesia. This was statistically insignificant.

\begin{tabular}{|c|c|c|c|c|c|c|c|}
\hline \multirow[t]{2}{*}{$\begin{array}{l}\text { VAS } \\
\text { Score }\end{array}$} & \multicolumn{2}{|c|}{$\begin{array}{c}\text { Group A } \\
\text { (No Analgesia) } \\
(n=39)\end{array}$} & \multicolumn{2}{|c|}{$\begin{array}{c}\text { Group B } \\
\text { (Bupivacaine) } \\
(n=39)\end{array}$} & \multicolumn{2}{|c|}{$\begin{array}{c}\text { Group C } \\
\text { (Bupivacaine Plus } \\
\text { Tramadol) } \\
\text { (n=39) }\end{array}$} & \\
\hline & No. & $\%$ & No. & $\%$ & No. & $\%$ & \multirow{7}{*}{$\begin{array}{l}\mathrm{P}< \\
0.05\end{array}$} \\
\hline $1-2$ & - & - & - & - & 2 & $\%$ & \\
\hline $3-4$ & - & - & 3 & $\%$ & 25 & $\%$ & \\
\hline $5-6$ & 6 & $15.38 \%$ & 36 & $\%$ & 12 & $\%$ & \\
\hline $7-8$ & 21 & $53.84 \%$ & - & - & - & - & \\
\hline $9-10$ & 12 & $30.76 \%$ & - & - & - & - & \\
\hline $\begin{array}{l}\text { Mean } \\
\pm \text { SD }\end{array}$ & \multicolumn{2}{|c|}{$8.47 \pm 0.79$} & \multicolumn{2}{|c|}{$5.07 \pm 0.63$} & \multicolumn{2}{|c|}{$4 \pm 0.95$} & \\
\hline \multicolumn{8}{|c|}{$\begin{array}{c}\text { Table 2. Comparison of Pain Perception during the Course } \\
\text { of Labour }\end{array}$} \\
\hline
\end{tabular}

\begin{tabular}{|c|c|c|c|c|c|}
\hline $\begin{array}{c}\text { No. of } \\
\text { Top Up } \\
\text { Dose }\end{array}$ & $\begin{array}{c}\text { Group B } \\
\text { (Bupivacaine) } \\
\text { (n = 39) }\end{array}$ & $\begin{array}{c}\text { Group C } \\
\text { (Bupivacaine Plus } \\
\text { Tramadol) } \\
\text { (n= 39) }\end{array}$ & \\
\hline & No. & $\mathbf{\%}$ & No. & \% & \\
\hline 1 & 3 & $7.69 \%$ & 26 & $66.66 \%$ & \multirow{2}{*}{$\mathrm{P}<0.05$} \\
\hline 2 & 33 & $84.61 \%$ & 13 & $33.33 \%$ & \\
\hline 3 & 3 & 7.69 & - & - & \\
\hline \multicolumn{7}{|c|}{ Table 3. Comparison According to Additional Top-Up Dose } \\
Requirement
\end{tabular}

\begin{tabular}{|c|c|c|c|c|c|}
\hline \multirow[t]{2}{*}{ Analgesia } & \multicolumn{2}{|c|}{$\begin{array}{c}\text { Group B } \\
\text { (Bupivacaine) } \\
(n=39)\end{array}$} & \multicolumn{2}{|c|}{$\begin{array}{c}\text { Group C } \\
\text { (Bupivacaine plus } \\
\text { Tramadol) } \\
(n=39) \\
\end{array}$} & \\
\hline & No. & $\%$ & No. & $\%$ & \\
\hline $\begin{array}{c}\text { Onset } \\
5-10 \text { min } \\
10-20 \\
\text { mins. } \\
>20 \text { mins. }\end{array}$ & $\begin{array}{l}- \\
27 \\
12\end{array}$ & $\begin{array}{c}- \\
69.23 \% \\
30.76 \%\end{array}$ & $\begin{array}{c}23 \\
12 \\
4\end{array}$ & $\begin{array}{l}58.91 \% \\
30.76 \% \\
10.25 \%\end{array}$ & $\mathrm{P}<0.05$ \\
\hline $\begin{array}{c}\text { Duration } \\
>3 \mathrm{hrs} . \\
2-3 \mathrm{hrs} . \\
<2 \mathrm{hrs} .\end{array}$ & $\begin{array}{c}6 \\
31 \\
2\end{array}$ & $\begin{array}{c}15.38 \% \\
79.48 \% \\
5.12 \%\end{array}$ & $\begin{array}{c}28 \\
10 \\
1\end{array}$ & $\begin{array}{c}71.79 \% \\
25.64 \% \\
2.5 \%\end{array}$ & $\mathrm{P}<0.05$ \\
\hline
\end{tabular}




\begin{tabular}{|c|c|c|c|c|c|}
\hline \multirow[t]{2}{*}{ Analgesia } & \multicolumn{2}{|c|}{$\begin{array}{c}\text { Group B } \\
\text { (Bupivacaine) } \\
\text { (n=39) }\end{array}$} & \multicolumn{2}{|c|}{$\begin{array}{c}\text { Group C } \\
\text { (Bupivacaine plus tramadol) } \\
(\mathrm{n}=39)\end{array}$} & \\
\hline & No. & $\%$ & No. & $\%$ & \\
\hline $\begin{array}{c}\text { Onset } \\
5-10 \text { mins. } \\
10-20 \text { mins. } \\
>20 \text { mins. }\end{array}$ & $\begin{array}{c}- \\
27 \\
12\end{array}$ & $\begin{array}{c}- \\
69.23 \% \\
30.76 \%\end{array}$ & $\begin{array}{c}23 \\
12 \\
4\end{array}$ & $\begin{array}{l}58.91 \% \\
30.76 \% \\
10.25 \%\end{array}$ & $P<0.05$ \\
\hline $\begin{array}{c}\text { Duration } \\
>3 \mathrm{hrs} . \\
2-3 \mathrm{hrs} . \\
<2 \mathrm{hrs}\end{array}$ & $\begin{array}{c}6 \\
31 \\
2\end{array}$ & $\begin{array}{c}15.38 \% \\
79.48 \% \\
5.12 \%\end{array}$ & $\begin{array}{c}28 \\
10 \\
1\end{array}$ & $\begin{array}{c}71.79 \% \\
25.64 \% \\
2.5 \%\end{array}$ & $\mathrm{P}<0.05$ \\
\hline
\end{tabular}

\begin{tabular}{|c|c|c|c|c|c|c|c|}
\hline & \multicolumn{2}{|c|}{$\begin{array}{c}\text { Group A } \\
\text { (No Analgesia) } \\
(n=39)\end{array}$} & \multicolumn{2}{|c|}{$\begin{array}{c}\text { Group B } \\
\text { (Bupivacaine) } \\
(\mathbf{n}=39)\end{array}$} & \multicolumn{2}{|c|}{$\begin{array}{c}\text { Group C } \\
\text { (Bupivacaine } \\
\text { plus Tramadol) } \\
(n=39)\end{array}$} & \\
\hline & No. & $\%$ & No & $\%$ & No & $\%$ & \\
\hline $\begin{array}{c}\text { Apgar Score at } 1 \text { mins. } \\
<5 \\
5-7 \\
>7 \\
\end{array}$ & $\begin{array}{c}2 \\
5 \\
32 \\
\end{array}$ & $\begin{array}{c}5.12 \% \\
12.82 \% \\
82.05 \% \\
\end{array}$ & $\begin{array}{c}1 \\
4 \\
34 \\
\end{array}$ & $\begin{array}{c}2.56 \% \\
10.25 \% \\
87.17 \% \\
\end{array}$ & $\begin{array}{c}1 \\
2 \\
36 \\
\end{array}$ & $\begin{array}{r}2.56 \% \\
5.12 \% \\
92.30 \% \\
\end{array}$ & $P>0.05$ \\
\hline $\begin{array}{c}\text { Apgar Score at } 5 \text { mins. } \\
<5 \\
5-7 \\
>7 \\
\end{array}$ & $\begin{array}{c}2 \\
5 \\
32 \\
\end{array}$ & $\begin{array}{c}5.12 \% \\
12.82 \% \\
82.05 \% \\
\end{array}$ & $\begin{array}{c}1 \\
4 \\
34\end{array}$ & $\begin{array}{c}2.56 \% \\
10.25 \% \\
87.17 \%\end{array}$ & $\begin{array}{c}1 \\
2 \\
36\end{array}$ & $\begin{array}{c}2.56 \% \\
5.12 \% \\
92.30 \%\end{array}$ & $P>0.05$ \\
\hline NICU Admission & 2 & $5.12 \%$ & 3 & $7.69 \%$ & 2 & $5.12 \%$ & $P>0.05$ \\
\hline
\end{tabular}

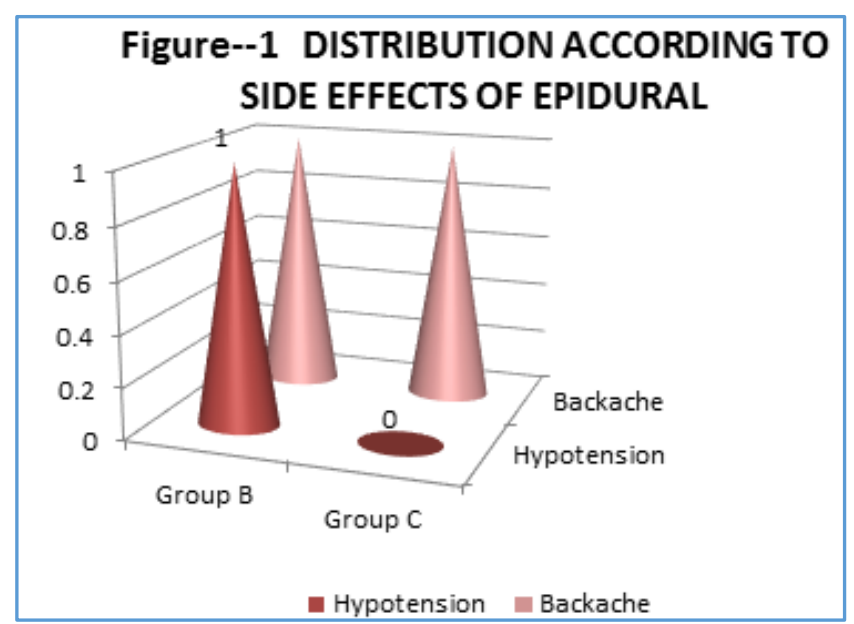

\section{Other Complications can be}

Rigor.

Nausea and vomiting.

Pruritus.

Dural puncture.

Urinary retention.

\section{DISCUSSION}

The study conducted on 117 patients consists of 3 groups Group A who received no analgesia, Group B who received Bupivacaine only, Group $\mathrm{C}$ who received Bupivacaine plus Tramadol.

Morr $\mathrm{AK}^{1}$ et al studied the influence of socio-economic status on the utilisation of epidural analgesia during labour.

In this study, the subjects in the Group $B$ and $C$ were more satisfied and experienced less pain than the after having epidural analgesia during the labour. There is highly significant association (Table 2).

In this study in Group A mean pain score was $8.47 \pm 0.79$, Group B $5.07 \pm 6.63$ and in Group C was $4 \pm 0.95$. There was statistical significant difference between all the three groups, $\mathrm{P}<0.001$. This was supported by the following studies. Howell $\mathrm{CJ}^{2}$ (2000) in their study concluded that epidural analgesia appears to be very effective in reducing pain during labour.

Morgan BM $^{3} 1980$ assessed the effects of epidural analgesia for uneventful labour. He found that $88 \%$ of the patients were completely satisfied with their pain relief; only $48 \%$ had completely painless labour after insertion of epidural catheter.

The study shows there is less top up dose required in Group C as compared to Group B (Table 3).

The study shows early onset and longer duration of analgesia in Group C as compared to Group B (Table 4). Our study was supportive by Deballi P, Breen TW4 (2000) Veena Chatrath, Ranjana Khetarpal, Sujata Sharma, Pratibha Kumari, Sudha $^{5}$ (2015). The study shows there was statistical highly significant difference in the degree of pain relief in Group A, B and $C(p<0.0001)$.

The study shows no significant difference between duration of 1st stage of labour in Group A, B and C.

The mean duration of 1 st stage of labour in primi gravida in Group A was 7.74 \pm 1.3 (mean \pm SD) hrs. in Group B was $6.65 \pm 1.3$ and in Group $C$ was $6.92 \pm 1.02$ (mean \pm SD) (Table $5)$. The duration of 1st stage of labour in multigravida in Group A was $4.3 \pm 1.2$ (mean \pm SD), in Group B $3.8 \pm 1.0$ and in Group C was $4.60 \pm 0.89$ (mean \pm SD). The association is statistically insignificant (Table 5). 
The duration of second stage of labour in primi gravida in Group A, B and C were 25.9 $\pm 8.12,31.09 \pm 5.94$ and 31.09 \pm 5.94 and in multigravida were $31.09 \pm 5.94,19.16 \pm 3.76$ and $23.75 \pm 4.78$ respectively. The duration of second stage of duration increases in Group B and Group C, but statistically insignificant (Table 5). Our study was conducted, was supported by the following studies.

A study was conducted by Wesam Farid Mousa et al ${ }^{6}$ (2012) on the effect of epidural analgesia on the duration of labour in primiparous parturient. Wide-ranging, it appears that it has no clear effect on the duration of the first stage, whereas the second stage is more constantly prolonged. The claimed association of epidural analgesia with prolonged delivery has long been attributed to motor blockade with concomitant weakness of pelvic floor muscles that reduces the effective maternal pushing and the involuntary bearing down reflex; however, this is not the case when dilute anaesthetics are used where motor blockade is minimal. Conversely, there is evidence to demonstrate that epidural analgesia may accelerate labour as the provision of effective analgesia reduces maternal catecholamine, and hence minimising its inhibitory effect on uterine contractility.

Our study was supported by the following studies of Mousa WF, et $\mathrm{al}^{7}$ (2012) aimed to evaluate the effect of epidural analgesia on labour duration compared with parturient devoid of analgesia. They found that there was no statistical difference in the duration of the active-first and the second stages of labour, instrumental delivery and vacuumassisted caesarean delivery rates. Rao $\mathrm{ZA}^{8}$ et al studied the walking epidural with low dose bupivacaine plus tramadol on normal labour in primipara.

The study shows no statistical significant difference in the rate of caesarean delivery and vacuum-assisted and instrumental delivery rates. Our study was supported by the following studies (Table 5), Wesam Farid Mousa et al ${ }^{6}$ (2012) in their study. The caesarean delivery as well as vacuumassisted and instrumental delivery rates were not significantly different between both the groups. The results of their study provide further support to the findings of other studies. Roberts $\mathrm{CL}^{9}$ et al studied the impact of first-stage ambulation on mode of delivery among women with epidural analgesia.

Fling $\mathrm{BK}^{10}$ (2000) concluded that continuous epidural analgesia for pain relief during labour would not increase the rate of caesarean delivery. In contrast, it may reduce this risk in nulliparous.

Further support to our results was given by Klein who reported that epidural analgesia when given before the active phase of labour would double the probability of receiving a caesarean section, while if given in the active phase of labour it would not increase the rate of caesarean section, which was the case in our study as we initiated the epidural analgesia at $4 \mathrm{~cm}$ cervical dilatation.

The study shows there is no statistical significance of Apgar score at 1 minute and Apgar score at 5 minutes (Table 6).

Mattingly JE 11 et al studied effects of obstetric analgesia and anaesthesia on the neonate. Epidural analgesia avoids foetal exposure to depressant drugs, improves placental perfusion and oxygenation of foetus.
The study shows distribution according to side effects. Hypotension occurred in 2 patients out of 78 patients and backache occurred in 1 patient (Figure 1).

\section{CONCLUSION}

Epidural analgesia is an effective method of pain relief. Instead of Bupivacaine alone, Bupivacaine plus Tramadol is more effective for pain relief during labour as an epidural analgesia.

\section{Acknowledgements}

"Coming together is the beginning. Keeping together is progress. Working together is success." It is an excellence of team work. The credit goes to a number of helping hands without whom this work could not have been completed. I am grateful to Dr. Neena Gupta, Professor, Department of Obstetrics and Gynaecology, GSVM Medical College, Kanpur and Dr. Sachidanand Gupta, Associate Professor, Department of Anaesthesiology, Rama Medical College, Kanpur for her valuable suggestions.

\section{REFERENCES}

1. Morr AK, Broscheit J, Blissing S, et al. Influence of socioeconomic status on the utilization of epidural analgesia during labour. Z Geburtshilfe Neonatol 2007;211(1):23-6.

2. Howell CJ. Epidural versus non-epidural analgesia for pain relief in labour. Cochrane Database Syst Rev 2000;2:CD000331.

3. Morgan B, Bulpitt CJ, Clifton P, et al. Effectiveness of pain relief in labour: survey of 1000 mothers. Br Med J (Clin Res Ed) 1982;11:285(6343):689-90.

4. DeBalli P, Breen TW. Intrathecal opioids for combined spinal-epidural analgesia during labour. CNS Drugs 2003;17(12):889-904.

5. Chatrath V, Khetarpal R, Sharma S, et al. Fentanyl versus tramadol with levobupivacaine for combined spinalepidural analgesia in labor. Saudi Journal of Anesthesia 2015;9(3)263-7.

6. Mousa WF, Al-Metwalli R, Mostafa M: Epidural analgesia during labor vs no analgesia: a comparative study. Saudi J Anaesth 2012;6(1):36-40.

7. Mousa WF, Al-Metwalli RR, Mostafa M. Epidural analgesia during labor- $0.5 \%$ lidocaine with fentanyl vs $0.08 \%$ ropivacaine with fentanyl. Middle East J Anesthesiol 2010;20(4):521-7.

8. Rao ZA, Choudhri A, Naqvi S, et al. Walking epidural with low dose bupivacaine plus tramadol on normal labour in primipara. J Coll Physicians Surg Pak 2010;20(5):295-8.

9. Roberts CL, Algert CS, Olive E. Impact of first-stage ambulation on mode of delivery among women with epidural analgesia. Aust N Z J Obstet Gynaecol 2004;44(6):489-94.

10. Fung BK. Continuous epidural analgesia for painless labor does not increase the incidence of cesarean delivery. Acta Anaesthesiol Sin 2000;38(2):79-84.

11. Mattingly JE, D'Alessio J, Ramanathan J. Effects of obstetric analgesics and anesthetics on the neonate: a review. Paediatric Drugs 2003;5(9):615-27. 